\title{
Fig Vinegar as an Antioxidant and Antimicrobial Agent
}

\author{
Gülden Kılıç̣, , İlkin Yücel Şengün ${ }^{1, b, *}$ \\ ${ }^{1}$ Food Engineering Department, Engineering Faculty, Ege University, 35100 Bornova/İzmir, Turkey
}

*Corresponding author

\begin{tabular}{l|l} 
A R T I C L E I N F O & A B S T R A C T \\
\hline $\begin{array}{l}\text { Research Article } \\
\text { Received : } 21 / 02 / 2021\end{array}$ & $\begin{array}{l}\text { Fig vinegar is a special product which has a long history and is handed down from generation to } \\
\text { generation. In the current study, characteristics of homemade fig vinegars supplied from different } \\
\text { cities of Turkey were compared in terms of their physicochemical, antioxidant and antimicrobial } \\
\text { properties. Physicochemical properties of the samples were very diverse. Total phenolic and } \\
\text { flavonoid content, and ABTS }{ }^{+} \text {and DPPH radical scavenging activities of the samples were ranged } \\
\text { from } 313.5 \text { to } 594.25 \mathrm{mg} \text { GAE/L and } 42.52-132.42 \mathrm{mg} \text { catechin/L, and } 0.44-3.98 \mu \mathrm{TE} / \mathrm{mL} \text { and } \\
1.25-7.51 \mu \mathrm{TE} / \mathrm{mL} \text {, respectively. The antioxidant activity of vinegars is highly correlated with } \\
\text { their phenolic and flavonoid contents. Furthermore, vinegar samples exhibited inhibitive effect on } \\
\text { all test microorganisms and the minimum inhibition concentration values were ranged between } 0.39 \\
\text { and } 25 \%(\mathrm{v} / \mathrm{v}) . \text { These results indicated the distinct properties of homemade fig vinegars and the } \\
\text { potential of them as antimicrobial and antioxidant substances. }\end{array}$ \\
$\begin{array}{l}\text { Keywords: } \\
\text { Fig vinegar }\end{array}$ &
\end{tabular}

Fig vinegar

Physicochemical

Bioactivity

Minimum inhibition

Concentration

Antimicrobial

\section{Introduction}

Vinegar is an acidic liquid product obtained from various sources including fermentable carbohydrates by the activity of Saccharomyces cerevisiae and acetic acid bacteria (AAB). It is also possible to produce vinegar from liquid containing ethanol such as wine (Sengun, 2015). Acetic acid produced by $\mathrm{AAB}$ during vinegar production is responsible for characteristic aroma of vinegar. There are very types of vinegar produced worldwide such as cereal vinegar, wine vinegar, fruit vinegar, traditional balsamic vinegar and cider vinegar. It is provided by firms that large scale production and/or produced in small scales traditionally, which have changed from region to region (Giudici et al., 2017).

Recently, the popularity of vinegars prepared at homes from a variety of substrates has been increased. Although the substrates and the final products in homemade vinegar productions have some variations, the process always includes alcoholic and acetous fermentation, which are the main steps of vinegar production (Rosma et al., 2016). Unlike commercial vinegars, they are produced under uncontrolled conditions and consumed without pasteurization. Hence, it may provide a suitable environment for the growth of undesirable microorganisms. It is noted that the presence of sufficient amount of acid is essential to obtain high quality vinegars (Giudici et al., 2017).

Different plant species and products are used in the treatment of diseases in many parts of the world (Sevindik et al., 2017; Mohammed et al., 2019; Pehlivan et al., 2018; Mohammed et al., 2020). Vinegar has long been used in both natural folk medicine and traditional medicine for treating a variety of diseases. It is provided beneficial health effects including anticarcinogenic, antidiabetic, antiglycemic, antihypertensive, antimicrobial, antioxidant and lipid-lowering when consumed regularly due to including variety of organic acids, phenolic compounds, amino acids, vitamins, melanoidins (Karabiyikli and Sengun, 2017). Several researchers demonstrated that different kinds of vinegars effectively inhibit the growth of foodborne pathogens including Bacillus cereus, Aeromonas hydrophila, Vibrio parahaemolyticus, Escherichia coli 0157:H7, Salmonella enteritidis, S. typhimurium, Staphylococcus aureus, and could be used for disinfection of food, food preparation surfaces and equipment (Karabiyikli and Sengun, 2017). 
There is a limited knowledge on traditional homemade vinegars produced from different kinds of raw materials. Fig (Ficus carica L.) is grown in large areas in Turkey and used as raw material of fig vinegar (Harzallah et al., 2016). The quality properties of fig vinegar, which is produced by fresh and/or dried figs show differences depending on the production techniques and raw material used. There are several studies investigating the antioxidant activities and phenolic contents of vinegars produced from various fruits, mainly grape and apple. However, except our previous studies (Sengun et al., 2020; Şengün and Kılıç, 2020a, b), there are no studies determining the properties of fig vinegar including total phenolic content, total flavonoid content, antioxidant and antimicrobial activities.

Therefore, the purpose of the current study was to examine some properties of traditional fig vinegar supplied from different cities of Turkey in terms of their physicochemical, antioxidant and antimicrobial properties.

\section{Materials and Methods}

\section{Materials}

In the study, traditionally produced homemade fig vinegars were collected from various cities (Sample A from Aydin, Sample B from Gaziantep, Sample C and D from Izmir) in Turkey. Vinegar production was performed using two different varieties of figs grown in Aydin (Morguz-dark color), Gaziantep (Sari Lop-light color) and Izmir (Sari Lop and Sari Zeybek-light color) cities. The production steps include mixing fresh fruits and water (1:1), first fermentation (at room temperature for 2 weeks), filtration, second fermentation (at room temperature for 10-12 weeks) and bottling. Vinegar samples were stored at $4^{\circ} \mathrm{C}$ before used in the experiments.

\section{Methods}

\section{Physicochemical Analysis}

The $\mathrm{pH}$ values of vinegars were determined by using pH meter (NEL Mod 821) (AOAC, 2007).

Acidity values of vinegars such as total, volatile and non-volatile were examined by titrimetric method. The results of these analyses were given as g acetic acid/100 $\mathrm{mL}$ of sample (AOAC, 2007).

Residual alcohol and specific weight of vinegars were examined by picnometric method. The results of these analyses were given as \% (AOAC, 2007).

Brix values of vinegar samples were determined by refractometer (Hanna HI 96801), values were expressed as Brix (AOAC, 2007).

Ash contents of vinegar samples were detected by ashing the samples at $525^{\circ} \mathrm{C}$ to constant weight and the results of this analysis were given as $\mathrm{g} / \mathrm{L}$ (AOAC, 2007).

Color values of the samples were determined using a HunterLab Colorflex (Management Company, USA) calibrated with standard calibration scale and the color properties of the samples were given as $L^{*}, a^{*}$, and $b^{*}$ (Rommel et al., 1990).

\section{Total Phenolic Content}

The amounts of total phenolic contents of vinegars were detected by the colorimetric Folin-Ciocalteu method. $1 \mathrm{~mL}$ of filtered $(0.2 \mu \mathrm{m}$, Sartorius Stedim) vinegar, $5 \mathrm{~mL}$ of $10 \%$ Folin-Ciocalteu's phenol reagent (Sigma-Aldrich) and $75 \mathrm{~mL}$ of distilled water were mixed. After the mixture was held at room temperature for $3 \mathrm{~min}, 10 \mathrm{~mL}$ saturated $\mathrm{Na}_{2} \mathrm{CO}_{3}$ (Merck) was transferred to the mixture. The obtained mixture was complemented to $100 \mathrm{~mL}$ with distilled water and kept for $90 \mathrm{~min}$ in the dark. Then the absorbance value of this mixture was determined by a spectrophotometer (Cary60 UV-Visible, Agilent Technologies) at $720 \mathrm{~nm}$ (Cemeroglu, 2013). Total phenolic content of vinegars was given as $\mathrm{mg}$ of gallic acid equivalents/L (mg GAE/L).

\section{Total Flavonoid Content}

The amounts of total flavonoid contents of vinegars were detected with spectrophotometric method (Zhishen et al., 1999). $4 \mathrm{~mL}$ of distilled water and $1 \mathrm{~mL}$ of filtered vinegar $(0.2 \mu \mathrm{m}$, Sartorius Stedim) was mixed. Then 0.3 $\mathrm{mL}$ of $10 \% \mathrm{AlCl}_{3}$ (Merck), $0.3 \mathrm{~mL}$ of $5 \% \mathrm{NaNO}_{2}$ (Merck) and $2 \mathrm{~mL}$ of $1 \mathrm{M} \mathrm{NaOH}$ (Merck) were transferred to the mixture. The obtained mixture was completed to $10 \mathrm{~mL}$ with distilled water, and then the absorbance value of the mixture was detected using a spectrophotometer (Cary60 UV-Visible, Agilent Technologies) at $510 \mathrm{~nm}$. The amount of total flavonoid contents of vinegars were given as catechin equivalents (mg catechin/L).

Antioxidant Activity

The antioxidant activities of vinegars were analyzed according to the ABTS and DPPH methods.

ABTS radical scavenging activities vinegars were detected as described by Re et al. (1999). After dissolving $37.5 \mathrm{mg}$ of $\mathrm{K}_{2} \mathrm{~S}_{2} \mathrm{O}_{8}$ (Sigma-Aldrich) and $10 \mathrm{mg}$ of $\mathrm{ABTS}^{+}$ [2,2'-azino-bis (3-ethylbenzothiazoline-6-sulphonic acid) (Sigma-Aldrich)] in 1 and $2.57 \mathrm{~mL}$ of distilled water, respectively, and both solutions were mixed and stored in the dark for 12-16 hour to obtain ABTS radical cation $\left(\mathrm{ABTS}^{+}\right.$) solution. After that, to obtain absorbance value of $0.70 \pm 0.02$ at $734 \mathrm{~nm}, 1 \mathrm{~mL}$ of $\mathrm{ABTS}^{+}$solution was diluted with ethanol. Furthermore, $\mathrm{ABTS}^{+}$solution $(3 \mathrm{~mL})$ and filtered $(0.2 \mu \mathrm{m}$, Sartorius Stedim) vinegars $(300 \mu \mathrm{L})$ with concentrations in the range of $100-500 \mu \mathrm{g} / \mathrm{mL}$, were mixed and stored for $6 \mathrm{~min}$ in the dark. Then the absorbance of this mixture was detected using a spectrophotometer (Cary60 UV-Visible, Agilent Technologies) at $734 \mathrm{~nm}$. The percent inhibition of $\mathrm{ABTS}^{+}$was measured as given below:

$$
\% \mathrm{ABTS}^{+}=\left(\mathrm{A}_{\mathrm{c}}-\mathrm{A}_{\mathrm{s}}\right) \times 100 / \mathrm{A}_{\mathrm{c}}
$$

Where;

$\mathrm{A}_{\mathrm{s}}=$ is absorbance of sample

$\mathrm{A}_{\mathrm{c}}=$ is absorbance of $\mathrm{ABTS}^{+}$solution.

Calibration curve was prepared using Trolox (50-500 $\mu \mathrm{g} / \mathrm{mL})$ and the antioxidant capacity was given as $\mu \mathrm{g}$ of Trolox equivalents/mL ( $\mu \mathrm{g} \mathrm{TE} / \mathrm{mL})$.

DPPH radical scavenging capacity of vinegars was also examined by the modified method of Cemeroglu (2013). Filtered the sample $(0.2 \mu \mathrm{m}$, Sartorius Stedim) at various concentrations (20-100 $\mu \mathrm{L})$ was transferred to $300 \mu \mathrm{L}$ of $0.1 \mathrm{mM}$ 2,2-Diphenyl-1-picrylhydrazyl (DPPH, SigmaAldrich). After methanol was added to the obtained mixture until $3 \mathrm{~mL}$ was reached, it was held in the dark for $15 \mathrm{~min}$ at room temperature. After that, the absorbance value of this mixture was determined by a spectrophotometer (Cary60 UV-Visible, Agilent Technologies) at $517 \mathrm{~nm}$. 
The percentage inhibition was expressed as given below:

$$
\operatorname{Abs}(\%)=\left(\mathrm{A}_{\mathrm{c}}-\mathrm{A}_{\mathrm{s}}\right) \times 100 / \mathrm{A}_{\mathrm{c}}
$$

Where;

$\mathrm{A}_{\mathrm{s}}$ is absorbance value of sample

$\mathrm{A}_{\mathrm{c}}$ is absorbance value of control (methanol).

The results were given as $\mu \mathrm{g}$ Trolox equivalents/mL ( $\mu \mathrm{g} \mathrm{TE} / \mathrm{mL})$.

Antimicrobial Activity

Antimicrobial properties of vinegars were detected by determining minimum inhibition concentration (MIC) and minimum bactericidal concentration (MBC). Bacillus subtilis ATCC 6037, Enterococcus faecalis ATCC 29212, Escherichia coli ATCC 1103, E. coli O157:H7 ATCC 43895, Listeria monocytogenes Scott A, Salmonella typhimurium NRRL-B-4420, Staphylococcus aureus 6538P, and Pediococcus acidilactici ATCC 8042 were utilized as test microorganisms. This study is mainly focused on the pathogens (E. coli, E. coli O157:H7, L. monocytogenes, S. typhimurium, $S$. aureus) associated with food-borne diseases, also representative species for LAB (E. faecalis and $P$. acidilactici) and food spoilage bacteria (B. subtilis) have been contained. All test microorganisms were supplied from Laboratory of Food Microbiology, Department of Food Engineering, University of Ege, Turkey. The test microorganisms stored at $-20^{\circ} \mathrm{C}$ were reactivated in Mueller Hilton Broth (MHB, pH $7.3 \pm 0.2$, Oxoid) at $37^{\circ} \mathrm{C}$ for $18-24$ $\mathrm{h}$. The test microorganisms having the turbidity standard of 0.5 McFarland (DEN-1 McFarland Densitometer, Grantbio) were utilized in the analyses.

For detecting MIC values of the samples, microdilution method was performed using standard 96-well microtiter plates (Deng et al., 2014). Dilutions of vinegars prepared in MHB (a total volume of $200 \mu \mathrm{L}$ ) and distributed in wells of the plate. The final concentrations of the samples in the wells of the prepared microplate were in the range of $50 \%$ $-0.10 \%(\mathrm{v} / \mathrm{v})$. After that, $10 \mu \mathrm{L}$ of the test microorganism was inoculated in each well. The wells including only the test cultures and MHB were used as positive and negative controls, respectively. The analyze was separately repeated for each test microorganism and for each vinegar sample. After incubation (at $37^{\circ} \mathrm{C}$ for $18 \mathrm{~h}$ ), $20 \mu \mathrm{L}$ of $2,3,5$ triphenyl tetrazolium chloride $(0.5 \%, \mathrm{w} / \mathrm{v}$, Merck) aqueous solution was mixed in the wells of the microplate and incubated again for $30 \mathrm{~min}$ at $37^{\circ} \mathrm{C}$, and the change of colors was observed. The lowest concentration of the sample necessary to inhibit observable growth of the test microorganisms was determined as the MIC value.

After determining the MIC values, to detect MBCs of vinegars (Tomas-Menor et al., 2013), inoculum was transferred from the first wells, where no color change was seen and on Mueller Hilton Agar (MHA, pH 7.3 \pm 0.2 , Oxoid) by streaking, and incubated at $37^{\circ} \mathrm{C}$ for $24 \mathrm{~h}$ were checked for colony formation.

\section{Statistical Analysis}

Analyses were conducted in three replicates and two parallels. Data were examined by one-way ANOVA using the SPSS software version 20. Differences among the means were evaluated by using Duncan's Multiple Range test at a significance level of $\mathrm{P}<0.05$. In tables and figures, the values were given in terms of mean values and standard deviation.

\section{Results and Discussions}

\section{Physicochemical Properties}

Total acidity and $\mathrm{pH}$ values of fig vinegars were ranged from 1.93 to $4.47 \mathrm{~g}$ acetic acid $/ 100 \mathrm{~mL}$ and $3.51 \pm 0.02$ to $3.75 \pm 0.21$, respectively (Table 1 ). Except sample A, our results were not in conformity with FDA (United States Food and Drug Administration) and Turkish Standards, who declare that total acidity value of vinegar should be at least $4 \%$ acidity. The acidity is one of the main parameters of vinegars. In the previous study, the $\mathrm{pH}$ value and total acidity of fig vinegar were determined as 3.22 and $4.73 \mathrm{~g}$ acetic acid/100 mL (Sengun et al., 2020). Volatile and nonvolatile acidity of vinegars were determined as in the range of 1.25 and $3.67 \mathrm{~g}$ acetic acid/100 mL, and 0.24 and $1.20 \mathrm{~g}$ acetic acid/100 $\mathrm{mL}$, respectively (Table 1). Figs used as raw material in the study were belong to different varieties and grown in different locations. Hence, it could be reason of the variation of acidic values of vinegars. Giudici et al. (2017) also stated that the concentration of acetic acid, which is the main parameters of vinegars, is related with the raw material, the microorganisms involved during vinegar production and the technology employed.

Residual alcohol content is other important quality criteria for vinegars. In an ideal vinegar production, all alcohol in the medium is expected to be converted to acetic acid, and this case represents efficiency of vinegar (Giudici et al., 2017). It is stated that residual alcohol content of vinegar should be at most $0.5 \%$ (v/v) except wine vinegars (Anonymous, 2016). However, this value was ranged between 2.04 and $3.09 \%$ in this study (Table 1).

Brix and specific weights of fig vinegar samples varied in a wide range from 1.30 to 21.2 and 0.9955 to 0.9970 , respectively (Table 1). In another studies, brix values of various vinegars were reported as ranging between 3.30 and 3.40 for alcohol vinegar, 3.80-5.00 for wine vinegar (Saiz-Abajo et al., 2004), 1.00-20.80 for apple, applelemon, apricot, artichoke, blackberry, fig, grape, hawthorne, mandarin, mulberry, lemon, persimmon, plum, pomegranate, rosehip, sour cherry vinegar (Budak, 2015; Ozturk et al., 2015; Sengun et al., 2020) and above 55 for traditional balsamic vinegar (Masino et al., 2008). As it can be seen from the studies, brix value shows characteristic properties of vinegar and may change depending on the type of vinegar and the raw material used during production (Saiz-Abajo et al., 2004; Masino et al., 2008).

The amount of ash was expressed as unburned inorganic materials found in samples. In the study, ash contents of fig vinegars were found between $2.6 \mathrm{~g} / \mathrm{L}$ and $11.5 \mathrm{~g} / \mathrm{L}(\mathrm{P}<0.05)$ (Table 1). Other researchers stated that ash contents of grape and wine vinegars ranged between 0.74-3.56 g/L and 2.03-2.61 g/L, respectively (Gerbi et al., 1998; Akbas and Cabaroglu, 2010). Hence, the ash content of fig vinegars is much higher compared to the other vinegars. These results can be related to the fact that the fig fruit is a rich source in terms of mineral content (Vinson, 1999). 
Table 1. Physicochemical properties of fig vinegars

\begin{tabular}{|c|c|c|c|c|}
\hline Analysis & $\mathrm{A}$ & $\mathrm{B}$ & $\mathrm{C}$ & $\mathrm{D}$ \\
\hline $\mathrm{pH}$ & $3.75 \pm 0.21^{\mathrm{a}}$ & $3.57 \pm 0.03^{\mathrm{a}}$ & $3.51 \pm 0.02^{\mathrm{a}}$ & $3.67 \pm 0.01^{\mathrm{a}}$ \\
\hline Total acidity $(\mathrm{g} / 100 \mathrm{~mL})^{*}$ & $4.87 \pm 0.33^{c}$ & $3.17 \pm 0.14^{\mathrm{b}}$ & $2.16 \pm 0.09^{a}$ & $1.93 \pm 0.13^{\mathrm{a}}$ \\
\hline Volatile acidity $(\mathrm{g} / 100 \mathrm{~mL})^{*}$ & $3.67 \pm 0.33^{\mathrm{d}}$ & $2.69 \pm 0.14^{\mathrm{c}}$ & $1.92 \pm 0.09^{b}$ & $1.25 \pm 0.13^{\mathrm{a}}$ \\
\hline Non-volatile acidity $(\mathrm{g} / 100 \mathrm{~mL})^{*}$ & $1.20 \pm 0.00^{\mathrm{d}}$ & $0.48 \pm 0.00^{\mathrm{b}}$ & $0.24 \pm 0.00^{\mathrm{a}}$ & $0.68 \pm 0.00^{\mathrm{c}}$ \\
\hline Brix $^{\circ}$ & $21.2 \pm 0.00^{\mathrm{d}}$ & $1.80 \pm 0.00^{\mathrm{b}}$ & $1.30 \pm 0.00^{\mathrm{a}}$ & $2.30 \pm 0.00^{\mathrm{c}}$ \\
\hline Residual alcohol $\left(\%, 20^{\circ} \mathrm{C}\right)$ & $2.04 \pm 0.00^{\mathrm{a}}$ & $2.52 \pm 0.00^{\mathrm{b}}$ & $2.59 \pm 0.00^{\mathrm{b}}$ & $3.09 \pm 0.00^{c}$ \\
\hline Specific weight & $0.9970 \pm 0.0^{\mathrm{c}}$ & $0.9963 \pm 0.0^{\mathrm{b}}$ & $0.9962 \pm 0.0^{\mathrm{b}}$ & $0.9955 \pm 0.0^{\mathrm{a}}$ \\
\hline $\operatorname{Ash}(g / L)$ & $11.5 \pm 0.00^{\mathrm{d}}$ & $3.6 \pm 0.00^{\mathrm{c}}$ & $3.2 \pm 0.00^{\mathrm{b}}$ & $2.6 \pm 0.00^{\mathrm{a}}$ \\
\hline
\end{tabular}

Table 2. Antioxidant, total phenolic and total flavonoid contents of fig vinegars

\begin{tabular}{l|cccc}
\hline \multicolumn{1}{c}{ Analysis } & A & B & C & D \\
\hline Total phenolic content $(\mathrm{mg}$ GAE/L) & $594.25 \pm 6.01^{\mathrm{d}}$ & $313.5 \pm 8.48^{\mathrm{a}}$ & $444.25 \pm 8.13^{\mathrm{b}}$ & $383 \pm 6.36^{\mathrm{c}}$ \\
Total flavonoid content $(\mathrm{mg}$ catechin/L) & $132.42 \pm 0.53^{\mathrm{d}}$ & $48.52 \pm 0.26^{\mathrm{a}}$ & $110.11 \pm 0.16^{\mathrm{c}}$ & $69.14 \pm 0.47^{\mathrm{b}}$ \\
DPPH radical scavenging activity $(\mu \mathrm{g} / \mathrm{mL})^{*}$ & $7.51 \pm 0.69^{\mathrm{b}}$ & $1.49 \pm 0.01^{\mathrm{a}}$ & $2.09 \pm 0.05^{\mathrm{a}}$ & $1.25 \pm 0.007^{\mathrm{a}}$ \\
ABTS+ radical scavenging activity $(\mu \mathrm{g} / \mathrm{mL})^{*}$ & $3.98 \pm 0.001^{\mathrm{d}}$ & $0.44 \pm 0.003^{\mathrm{a}}$ & $0.73 \pm 0.00^{\mathrm{b}}$ & $0.97 \pm 0.002^{\mathrm{c}}$ \\
\hline
\end{tabular}

*: as TE. Standard deviation of means is shown as \pm SD. Values in the same row with different superscripts are significantly different $(\mathrm{P}<0.05)$.

Table 3. The minimum inhibition concentration (MIC) values of fig vinegars (v/v, \%)

\begin{tabular}{l|cccc}
\hline \multicolumn{1}{c|}{ Microorganisms } & $\mathrm{A}$ & $\mathrm{B}$ & $\mathrm{C}$ & $\mathrm{D}$ \\
\hline Bacillus subtilis & $0.39 \pm 0.00$ & $12.5 \pm 0.00$ & $12.5 \pm 0.00$ & $9.38 \pm 4.42$ \\
Enterococcus faecalis & $1.56 \pm 0.00$ & $12.5 \pm 0.00$ & $9.38 \pm 4.42$ & $12.5 \pm 0.00$ \\
Escherichia coli & $3.12 \pm 0.00$ & $6.25 \pm 0.00$ & $12.5 \pm 0.00$ & $9.38 \pm 4.42$ \\
Escherichia coli $\mathrm{O} 157: \mathrm{H} 7$ & $1.56 \pm 0.00$ & $6.25 \pm 0.00$ & $12.5 \pm 0.00$ & $6.25 \pm 0.00$ \\
Listeria monocytogenes & $1.56 \pm 0.00$ & $9.38 \pm 4.42$ & $12.5 \pm 0.00$ & $9.38 \pm 4.42$ \\
Salmonella typhimurium & $1.56 \pm 0.00$ & $12.5 \pm 0.00$ & $25 \pm 0.00$ & $9.38 \pm 4.42$ \\
Staphylococcus aureus & $6.25 \pm 0.00$ & $12.5 \pm 0.00$ & $12.5 \pm 0.00$ & $12.5 \pm 0.00$ \\
Pediococcus acidilactici & $12.5 \pm 0.00$ & $4.69 \pm 2.21$ & $9.38 \pm 4.42$ & $4.69 \pm 2.21$ \\
\hline
\end{tabular}

*Standard deviation of means is shown as $\pm \mathrm{SD}$.

Table 4. Minimum bactericidal concentration (MBC) values of fig vinegars (v/v, \%)

\begin{tabular}{l|cccc}
\hline \multicolumn{1}{c|}{ Microorganisms } & $\mathrm{A}$ & $\mathrm{B}$ & $\mathrm{C}$ & $\mathrm{D}$ \\
\hline Bacillus subtilis & $3.12 \pm 0.00$ & $>50$ & $>50$ & $>50$ \\
Enterococcus faecalis & $12.5 \pm 0.00$ & $>50$ & $>50$ & $>50$ \\
Escherichia coli & $50 \pm 0.00$ & $>50$ & $>50$ & $>50$ \\
Escherichia coli O157:H7 & $>50$ & $>50$ & $>50$ & $>50$ \\
Listeria monocytogenes & $12.5 \pm 0.00$ & $>50$ & $>50$ & $>50$ \\
Salmonella typhimurium & $25 \pm 0.00$ & $>50$ & $>50$ & $>50$ \\
Staphylococcus aureus & $50 \pm 0.00$ & $>50$ & $>50$ & $>50$ \\
Pediococcus acidilactici & $>50$ & $>50$ & $>50$ & $>50$ \\
\hline
\end{tabular}

*Standard deviation of means is shown as \pm SD.

\section{Color Properties}

Color properties of fig vinegar samples are shown in Figure 1 and $L^{*}, a^{*}, b^{*}$ values of the samples were determined as ranging between 5.36-15.42, -1.65-8.51 and 3.96-8.29, respectively $(\mathrm{P}<0.05)$. Among the samples, the highest $L^{*}$ and $a^{*}$ values were determined in sample B and C, respectively. Meanwhile, Sample A as the only sample produced from dark-colored figs (Morguz) has the highest $b^{*}$ value. Many researchers reported that the color properties of various vinegars show significant differences, which mainly change depending on the color of raw material used (Palacios et al., 2002; Lopez et al., 2005; Giudici et al., 2017). Besides, the technology employed during vinegar production could also affect the color of the product. For example, if the production steps include heat processing, the color of vinegar mainly comes to darker like in balsamic vinegar.

\section{Antioxidant Activities}

The total phenolic contents of the samples ranged between $313.5 \mathrm{mg} \mathrm{GAE} / \mathrm{L}$ and 594.25 $\mathrm{mg} \mathrm{GAE} / \mathrm{L}(\mathrm{P}<0.05)$ (Table 2). Many researchers reported different total phenolic contents for various vinegars, such as $4684.50 \mathrm{mg}$ GAE/L for apple vinegar, $32761.33 \mathrm{mg}$ GAE/L for pomegranate vinegar, 2000-3000 $\mathrm{mg}$ GAE/L for grape vinegars, 200-1000 mg GAE/L for Spanish wine vinegar, $3092 \mathrm{mg} \mathrm{GAE} / 100 \mathrm{~g}$ for pepper leave vinegar, $823.07 \mathrm{mg}$ GAE/L for pomegranate vinegar, $481.40 \mathrm{mg}$ GAE/L for young Sherry vinegar, $563.73 \mathrm{mg} \mathrm{GAE} / \mathrm{L}$ for Reserva Sherry vinegar, 1051-4086 mg GAE/L for Shanxi aged vinegar (Alonso et al., 2004; Budak and Guzel-Seydim, 2010; Song et al., 2014; Aykın et al., 2015; Kharchoufi et al., 2018; Xia et al., 2018).

There is a positive correlation between the amount of total phenolic and flavonoid content. The total flavonoids 
of fig vinegars were in the range of $48.52-132.42 \mathrm{mg}$ catechin/L (Table 2). The results showed that the highest total flavonoid and also phenolic contents were obtained in Sample A, which is the only sample produced from darkcolored figs. Hence, it could be concluded that there is positive correlation between the darkness of figs and the total flavonoid and phenolic contents of vinegar. Although the color values $\left(b^{*}\right)$ of some samples close to each other ( $\mathrm{P}>0.05)$, such as in Sample B and C (samples grown in different cities, but belong to same variety-Sari Lop) or in Sample B (Sari Lop) and D (Sari Zeybek) (samples belong to different varieties and grown in different cities) (Figure 1), total phenolic and flavonoid contents of these samples were statistically different from each other $(\mathrm{P}<0.05)$. In the previous study, the total phenolic and flavonoid contents of fig vinegar were determined as $935.5 \mathrm{mg} \mathrm{GAE} / \mathrm{L}$ and $178.45 \mathrm{mg}$ catechin/L, respectively (Sengun et al., 2020), which were higher than the results of the current study. In the literature, wide variety of total flavonoid contents were also reported for different vinegars, such as 14.43-349.05 $\mathrm{mg}$ catechin/L for homemade grape vinegars, 10.89-188.43 $\mathrm{mg}$ catechin/L for homemade apple vinegars (Ozturk et al., 2015) and 1655-3999 mg Rutin equivalent/L for nine different Shanxi aged vinegars (Xia et al., 2018). All these results confirm that the amount of total phenolic and flavonoid contents of vinegars may change depending on the variety and the growth area of fig fruit and the technology used during vinegar production.

There are numerous methods developed for the assessment of antioxidant activities of various materials (Sevindik et al., 2017; Mohammed et al., 2019). The outcomes of the methods based on the deactivation of radicals, such as DPPH and ABTS, differ inside reactions appearance and reaction kinetics (Layina-Pathirana et al., 2006; Mareček et al., 2017). As it can be seen from Table $2, \mathrm{DPPH}$ and $\mathrm{ABTS}^{+}$radical scavenging activities of fig vinegars varied in the range of $1.25-7.51 \mu \mathrm{g} \mathrm{TE} / \mathrm{mL}$ and 0.44-3.98 $\mu \mathrm{g} \mathrm{TE} / \mathrm{mL}$, respectively $(\mathrm{P}<0.05)$.

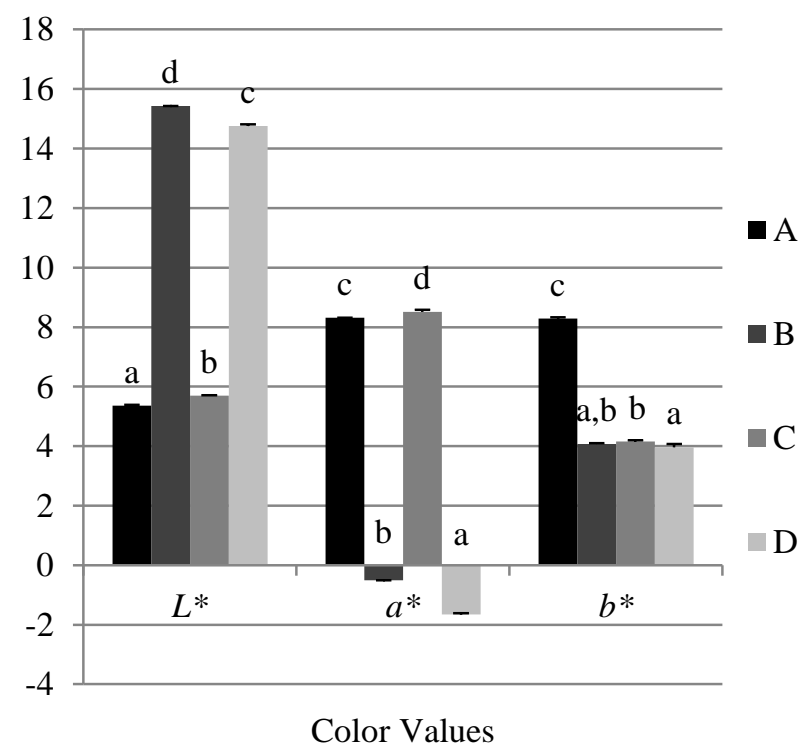

Figure 1. Color properties of fig vinegars (Different letters on data bars indicate a significant difference $(\mathrm{P}<0.05)$. Statistical analysis was applied separately for $L^{*}, a^{*}, b^{*}$ values).
As in parallel with the amount of total phenolic and flavonoid contents, the highest antioxidant activity was determined in Sample A. In the previous studies, wide range of antioxidant activities were reported for fruit vinegars, mainly for pomegranate, grape and apple vinegars (Budak et al., 2011; Bertelli et al., 2015; Ozturk et al., 2015; Bakir et al., 2017; Kharchoufi et al., 2018). However, there is no data about the antioxidant activity of fig vinegar. Hence, it is the first study to report antioxidant activity of fig vinegar, which is highly correlated with its total phenolic and flavonoid contents.

\section{The MIC and MBC Values}

The MICs of vinegar samples were determined against eight microorganisms using a 96-well microtiter plate method, containing the final concentrations of vinegar in the range of $0.10 \%-50 \%(\mathrm{v} / \mathrm{v})$. Vinegar samples were found inhibitive for all microorganisms tested at concentration $12.5 \%$ (MIC, v/v). Sample A, which has the highest acidic, phenolic and flavonoid contents showed stronger antimicrobial activities than other samples against test microorganisms, except $P$. acidilactici. The most sensitive bacteria to sample A were found as $B$. subtilis with MIC of $0.39 \%$. P. acidilactici and S. typhimurium was the most resistant bacteria against sample $\mathrm{A}$ and $\mathrm{C}$, respectively (Table 3). Moreover, bactericidal effect was determined only in sample A for all test microorganisms, except $E$. coli O157:H7 and $P$. acidilactici, and also the highest bactericidal effect was observed to $B$. subtilis with MBC of $3.12 \%$ (Table 4). In our previous study, the MIC value of fig vinegar on L. monocytogenes, E. faecalis, B. subtilis, S. aureus, E. coli O157:H7, S. Typhimurium, E. coli, B. cereus and $P$. acidilactici was determined in the range of 3.12$6.25 \%$, while the MBC value of the vinegar was $50 \%$ for all test cultures (Sengun et al., 2020). In a study carried out by Ozturk et al. (2015), B. cereus was determined as the most sensitive strain against traditionally produced fruit vinegars. In another study (Bakir et al., 2017), balsamic vinegar was shown the highest antimicrobial activity against $S$. typhimurium. All the results demonstrated that the antimicrobial activity of vinegars may change depending on the test culture and the amounts of acidity, total phenolic and flavonoid contents of vinegars.

\section{Conclusion}

The results of the study demonstrated that the properties of traditional fig vinegar vary in a wide range. Since the production of fig vinegar took place under uncontrolled conditions, some vinegar samples were not in conformity with the Standards, in terms of acidity and residual alcohol content. However, high levels of total phenolic and flavonoid contents, especially in the sample produced from dark colored figs (Sample A), were observed in vinegars, which lead to indicate high antioxidant activities. Besides, fig vinegars exhibited antimicrobial activity to all test bacteria in various sensitivities. Further analysis is needed to determine the phenolic profile of fig vinegar.

\section{Acknowledgements}

This work was supported by Ege University Scientific Research Project Commission for the project entitled "Microbiological, physical and chemical properties of fig vinegar produced by traditional methods" (Project No: 16MÜH-116). 


\section{References}

Akbas M, Cabaroglu T. 2010. A study on the composition of some grape vines produced in our country and their suitability for food legislation. Food Journal, 35(3): 183-188.

Alonso AM, Castro R, Rodriguez MC, Guillen DA, Barroso CG. 2004. Study of the antioxidant power of brandies and vinegars derived from Sherry wines and correlation with their content in polyphenols. Food Research International, 37: 715-721. doi: 10.1016/j.foodres.2004.03.007

Anonymous 2016. Vinegar - product made from liquids of agricultural origin - definitions, requirements, marking (Vol. TS 1880 EN 13188/D1:2016). Ankara.

AOAC, 2007. Official Methods of Analysis of the Association of Official Analytical Chemistry. 16th edition. AOAC International: Washington. ISBN 0935584544.

Aykın E, Budak NH, Güzel-Seydim ZB. 2015. Bioactive components of mother vinegar. Journal of the American College of Nutrition, 34(1): 80-89. doi: 10.1080/07315724.2014.896230

Bakir S, Devecioglu D, Kayacan S, Toydemir G, KarbanciogluGuler F, Capanoglu E. 2017. Investigating the antioxidant and antimicrobial activities of different vinegars. European Food Research and Technology, 243(12): 2083-2094. doi: 10.1007/s00217-017-2908-0

Bertelli D, Maietti A, Papotti G, Tedeschi P, Bonetti G, Graziosi R, Brandolini V, Plessi M. 2015. Antioxidant activity, phenolic compounds, and NMR characterization of balsamic and traditional balsamic vinegar of Modena. Food Analytical Methods, 8(2): 371-379. doi: 10.1007/s12161-014-9902-y

Budak HB, Guzel-Seydim ZB. 2010. Antioxidant activity and phenolic content of wine vinegars produced by two different techniques. Journal of the Science of Food and Agriculture, 90: 2021-2026.

Budak HN, Kumbul DD, Savas CM, Seydim AC, Kok-Tas T, Ciris IM, Guzel-Seydim ZB. 2011. Effects of apple cider vinegars produced with different techniques on blood lipids in high-cholesterol-fed rats. Journal of Agricultural and Food Chemistry, 59(12): 6638-6644. doi: 10.1021/jf104912h

Budak NH. 2015. Total antioxidant activity and phenolic contents with advanced analytical techniques in the mulberry vinegar formation process. Fruit Science, 2(2): 27-31.

Cemeroglu B. 2013. Food Analysis. Ankara: Food Technology Association Publications. ISBN 9786056341939.

Deng Y, Yang G, Yue J, Qian B, Liu Z, Wang D, Zhong Y, Zhao Y. 2014. Influences of ripening stages and extracting solvents on the polyphenolic compounds, antimicrobial and antioxidant activities of blueberry leaf extracts. Food Control, 38: 184-191. doi: 10.1016/j.foodcont.2013.10.023

Gerbi V, Zeppa G, Beltramo R, Carnacini A, Antonelli A. 1998. Characterization of white vinegars of different sources with artificial neural networks. Journal of the Science of Food and Agriculture, 78: 415-425. doi: 10.1002/(SICI)10970010(199811)78:3<417: AID-JSFA134>3.0.CO;2-8

Giudici P, De Vero L, Gullo M. 2017. Vinegars. In: Sengun IY (editor), Acetic Acid Bacteria: Fundamentals and Food Applications. Boca Raton: CRC Press, Taylor, Francis Group. pp. 261-287. ISBN 9781315153490.

Harzallah A, Bhouri AM, Amri Z, Soltana H, Hammami M. 2016. Phytochemical content and antioxidant activity of different fruit parts juices of three figs (Ficus carica L.) varieties grown in Tunisia. Industrial Crops and Products, 83: 255-267. doi: 10.1016/j.indcrop.2015.12.043

Karabiyikli S, Sengun IY. 2017. Beneficial Effects of Acetic Acid Bacteria and Their Food Products. In: Sengun IY (editor). Acetic Acid Bacteria: Fundamentals and Food Applications. Boca Raton: CRC Press, Taylor, Francis Group. pp: 321-342. ISBN 9781315153490.

Kharchoufi S, Gomez J, Lasanta C, Castro R, Sainz F, Hamdi M. 2018. Benchmarking laboratory-scale pomegranate vinegar against commercial wine vinegars: antioxidant activity and chemical composition. Journal of the Science of Food and Agriculture, 98(12): 4749-4758. doi: 10.1002/jsfa.9011
Layina-Pathirana CM, Shahidi F, Alasalvar C. 2006. Antioxidant activity of cherry laurel fruit (Laurocerasus officinalis Roem.) and its concentrated juice. Food Chemistry, 99: 121128. doi: 10.1016/j.foodchem.2005.06.046

Lopez F, Pescador P, Güell C, Morales ML, García-Parrilla MC, Troncoso AM. 2005. Industrial vinegar clarification by crossflow microfiltration: Effect on colour and polyphenol content. Journal of Food Engineering, 68(1): 133-136. doi: 10.1016/j.jfoodeng.2004.05.021

Mareček V, Mikyška A, Hampel D, Čejka P, Neuwirthová J, Malachová A, Cerkal R. 2017. ABTS and DPPH methods as a tool for studying antioxidant capacity of spring barley and malt. Journal of Cereal Science, 73: 40-45. doi: 10.1016/j.jcs.2016.11.004

Masino F, Chinnici F, Bendini A, Montevecchi G, Antonelli A. 2008. A study on relationships among chemical, physical, and qualitative assessment in traditional balsamic vinegar. Food Chemistry, 106(1): 90-95. doi: 10.1016/j.foodchem.2007. 05.069

Mohammed FS, Pehlivan M, Sevindik M. 2019. Antioxidant, antibacterial and antifungal activities of different extracts of Silybum marianum collected from Duhok (Iraq). International Journal of Secondary Metabolite, 6(4): 317-322.

Mohammed FS, Günal S, Şabik AE, Akgül H, Sevindik M. 2020. Antioxidant and Antimicrobial activity of Scorzonera papposa collected from Iraq and Turkey. Kahramanmaraş Sütçü İmam Üniversitesi Tarım ve Doğa Dergisi, 23(5): 1114-1118.

Ozturk I, Calıskan O, Tornuk F, Sagdic O. 2015. Antioxidant, antimicrobial, mineral, volatile, physicochemical and microbiological characteristics of traditional homemade Turkish vinegars. LWT-Food Science and Technology, 63: 144-151. doi: 10.1016/j.lwt.2015.03.003

Palacios V, Valcarcel M, Caro I, Perez L. 2002. Chemical and biochemical transformations during the industrial process of sherry vinegar aging. Journal of Agricultural and Food Chemistry, 50(15): 4221-4225. doi: 10.1021/jf020093z

Pehlivan M, Mohammed FS, Sevindik M, Akgul H. 2018. Antioxidant and oxidant potential of Rosa canina. Eurasian Journal of Forest Science, 6(4): 22-25.

Re R, Pellegrini N, Protegent A, Pannala A, Yang M, Rice-Evans C. 1999. Antioxidant activity applying an improved ABTS radical cation decolorization assay. Free Radical Biology and Medicine, 26: 1231-1237. doi: 10.1016/S08915849(98)00315-3

Rommel A, Heatherbell DA, Wrolstad RE. 1990. Red raspberry juice and wine: Effect of processing and storage on anthocyanin pigment composition, colour and appearance. Journal of Food Science, 55: 1011-1017. doi: 10.1111/j.13652621.1990.tb01586.x

Rosma A, Nadiah AHS, Raj A, Supwat T, Sharma S, Joshi VK. 2016. Acetic Acid Fermented Product. In: Joshi VK (editor). Indigenous Fermented Foods of South Asia. Florida: CRC Press, Taylor and Francis Group. pp: 598-635. ISBN 9781439887837

Saiz-Abajo MJ, Gonzales-Saiz JM, Pizarro C. 2004. Classification of wine and alcohol vinegar samples based on near-infrared spectroscopy, feasibility study on the detection of adulterated vinegar samples. Journal of Agricultural and Food Chemistry, 52(25): 7711-7719. doi: 10.1021/jf049098h Sengun IY. 2013. Microbiological and chemical properties of fig vinegar produced in Turkey. African Journal of Microbiological Research, 7: 2332-2338. doi: 10.5897/AJMR12.2275

Sengun IY. 2015. Acetic Acid Bacteria in Food Fermentations. In: Montet D, Ray RC (editors). Fermented Foods: Part 1. Biochemistry and Biotechnology. Boca Raton: CRC Press, Taylor and Francis Group. pp. 91-111. ISBN 9780429183768.

Sengun IY, Kilic G, Ozturk B. 2020. Screening physicochemical, microbiological and bioactive properties of fruit vinegars produced from various raw materials. Food Science and Biotechnology, 29: 401-408. doi: 10.1007/s10068-019-00678-6 
Sevindik M, Akgul H, Pehlivan M, Selamoglu Z. 2017. Determination of therapeutic potential of Mentha longifolia ssp. longifolia. Fresen Environ Bull, 26(7): 4757-4763.

Şengün IY, Kılıç G. 2020a. Total phenolic content and antibacterial activity of homemade fig and mulberry vinegar. Eskişehir Technical University Journal of Science and Technology C- Life Sciences and Biotechnology, 9(1): 89-97. doi: 10.18036/estubtdc.681028

Şengün IY, Kılıç G. 2020b. Survival of foodborne pathogens in homemade fig and mulberry vinegars. Turkish Journal of Agriculture-Food Science and Technology, 8(9): 1833-1839. doi: 10.24925/turjaf.v8i9.1833-1839.3303

SPSS, 2004. Statistical package, SPSS for windows, ver. 13.0. Chicago: SPSS, Inc.

Song YR, Shin NS, Baik SH. 2014. Physicochemical properties, antioxidant activity and inhibition of $\alpha$-glucosidase of a novel fermented pepper (Capsicum annuиm L.) leaves-based vinegar. International Journal of Food Science and Technology, 49: 2491-2498. doi: 10.1111/ijfs.12573
Tomas-Menor L, Morales-Soto A, Barrajón-Catalán E, RoldánSegura C, Segura-Carretero A, Micol V. 2013. Correlation between the antibacterial activity and the composition of extracts derived from various Spanish Cistus species. Food Chemistry and Toxicology, 55: 313-322. doi: 10.1016/j.fct.2013.01.006

Vinson JA. 1999. Functional food properties of figs. Cereal Foods World, 44(2): 82-87.

Xia T, Yao J, Zhang J, Duan W, Zhang B, Xie X, Xia M, Song J, Zheng Y, Wang M. 2018. Evaluation of nutritional compositions, bioactive compounds, and antioxidant activities of Shanxi aged vinegars during the aging process. Journal of Food Science, 83(10): 2638-2644. doi: 10.1111/1750-3841.14356

Zhishen J, Mengcheng T, Jianming W. 1999. The determination of flavonoid contents in mulberry and their scavenging effects on superoxide radicals. Food Chemistry, 64(4): 555-559. doi: 10.1016/S0308-8146(98)00102-2 